\title{
Long-term logging residue loadings affect tree growth but not soil nutrients in Pinus contorta Doug. ex Loud. forests
}

\author{
Xiaohua Wei ${ }^{1}$ - Michaela J. Waterhouse ${ }^{2} \cdot$ Guang $\mathrm{Qi}^{1} \cdot$ Jianping $\mathrm{Wu}^{3}$
}

Received: 27 August 2019 / Accepted: 28 May 2020 / Published online: 15 June 2020

(C) INRAE and Springer-Verlag France SAS, part of Springer Nature 2020

\begin{abstract}
- Key message The 19-year monitoring study revealed continuously positive and dynamic responses of tree growth to logging residue loadings. However, the lack of changes in soil nutrients suggested that increased growth might result from enhanced nutrient cycling with no net accumulation in the soil.

- Context Understanding how logging residue loadings affect soil nutrients and forest growth is critical for designing management strategies for sustaining long-term productivity in forest ecosystems.

- Aims We aimed to examine the relationships among logging residue loadings, soil nutrients, and tree growth over a long-term field experiment in lodgepole pine (Pinus contorta Doug. ex Loud.) forests.

- Methods We established a field experiment in 1996 to examine the responses of lodgepole pine growth and soil nutrients to four residue loading treatments in the central interior of British Columbia, Canada. The four treatments were removal of all residues on the forest floor $\left(\mathrm{N}, 0 \mathrm{mg} \mathrm{ha}^{-1}\right.$ ), residues loading similar to whole-tree harvesting (W, 35-45 mg ha ${ }^{-1}$ ), residues loading similar to stem-only harvesting $\left(\mathrm{S}, 60-70 \mathrm{mg} \mathrm{ha}^{-1}\right)$, and residues loading similar to that found in disease- or insect-killed forests (D, 100$120 \mathrm{mg} \mathrm{ha}^{-1}$ ).

- Results Logging residue loadings had significantly positive and dynamic effects on diameter and height growths. The logging residue loadings did not significantly change soil nutrients in mineral soil pools in the long run, and there was no difference in tree growth between the treatments $\mathrm{S}$ and $\mathrm{W}$ over the study period.

- Conclusion Logging residue loadings significantly improved tree growth. The lack of response of soil nutrients leads to the hypothesis that nutrient fluxes from logging residues might play a more important role in tree growth in lodgepole pine forests. Our results can have important implications for bio-energy production and designing of nature-based practices for sustainable forest productivity.
\end{abstract}

Keywords Sapling growth $\cdot$ Logging residue loading $\cdot$ Forest management implications $\cdot$ Lodgepole pine $\cdot$ Soil nutrients

Handling Editor: Andreas Bolte

Contribution of the co-authors XW acquired funding and designed the experiment. JW, MW, GQ and XW collected and analyzed the data. The authors jointly contributed to manuscript completion.

Jianping $\mathrm{Wu}$

jianping.wu@ynu.edu.cn

Xiaohua Wei

adam.wei@ubc.ca

Michaela J. Waterhouse

michaela.waterhouse@gov.bc.ca

Guang Qi

qiguang594@163.com
1 Department of Earth, Environmental and Geographic Sciences, University of British Columbia, 3333 University Way, Kelowna, BC V1V 1V7, Canada

2 Ministry of Forests, Lands and Natural Resource Operations, 200-640 Borland Street, Williams Lake, BC V2G 4T1, Canada

3 Laboratory of Ecology and Evolutionary Biology, and Yunnan Key Laboratory of Plant Reproductive Adaption and Evolutionary Ecology, Yunnan University, Kunming 650500, China 


\section{Introduction}

Harvesting or logging residue including litter and woody detritus plays an important role in regulating soil nutrients and tree growth in forest ecosystems globally (Bradford et al. 2016; Harmon et al. 2011). Various case studies have examined the effects of logging residue loading on soil productivity (Eisenbies et al. 2009; Walmsley et al. 2009; Wei et al. 1997) and tree growth (Nettles et al. 2015; Wei et al. 2012). Regional experiments investigating the impacts of harvesting and site management on forest production have also found the importance of logging residue from tropical to boreal forests (Morris et al. 2019; Nambiar and Kallio 2008). However, in spite of the growing interest in this subject, the effects of forest logging residue loading cannot be generalized in terms of the amount of residue loading, growth dynamics, and site characteristics (Clarke et al. 2015; Egnell 2017; Thiffault et al. 2011). For example, large replicated experimental designs conducted in Canada (14 experimental sites of the LTSP network-Morris et al. 2019) or in Europe (Olsson et al. 1996; Walmsley et al. 2009) did not find clear effects of residue removal on tree growth. In contrast, some significant effects of residue loadings on forest production have been detected in European regions (Egnell 2017; Vanguelova et al. 2010). The inconsistent responses of forest growth to logging residue loadings clearly suggest that more case studies are critically needed.

Growing recognition of the ecological role of logging residue loading has shifted the management paradigm from "what should we take from forests" to "what we should leave behind" (Scott and Dean 2006; Parolari and Porporato 2016). Some woody materials such as CWD and standing dead trees have been considered biological legacies as they take longer to decompose (Bradford et al. 2014; Janisch et al. 2005) and serve for recovery and growth of subsequent forests (Bradford et al. 2014; Harmon et al. 2011). Moreover, there is a practical question of how much residue loading should be maintained after logging. Identification of loading levels would have important implications for designing management practices such as choice of harvesting techniques and residue utilizations, application of slash burning, or nitrogen pollution to soil and surface waters from fine brash decay (Clarke et al. 2015; Jerabkova et al. 2011; Parolari and Porporato 2016; Wei et al. 2003). Thus, understanding of long-term relationships among logging residue loading, soil nutrients, and growth is prerequisite for determining suitable residue loading levels for maintaining long-term productivity in forest ecosystems.

Previous studies showed that the effects of logging residue loading on tree growth varied with forest age and structure of the next rotation (e.g., Thiffault et al. 2011). For example, Wei et al. (2012) found that the differences in seedling growth between various logging residue loadings were not detected in the first 3 years after treatment, but the difference between the highest and the lowest residue loading became statistically significant after that. It has been reported that average levels of logging residues can eliminate the site preparation disturbance from harvesting during the first 5 years (Eisenbies et al. 2005). After 10 years of treatment, removal of residues significantly reduced sapling growth in two Norway spruce stands (Jacobson et al. 2017). All above suggest that the relationships between logging residue loadings and tree growth are likely dynamic over time. However, the dynamics of tree growth in response to logging residue loadings at longer time scales are still unclear. The present study added additional 10-year measurements to the data reported by Wei et al. (2012), which would further improve understanding of the changes that contributed to the difference in tree growth.

Sustainable site management is important for achieving sustainable productivity in forest ecosystems (Sanchez et al. 2006). Previous studies showed that positive responses of seedling growth are normally expected from slash burning due to large amounts of nutrients released from the burning or through leaching of nutrients from the fine brash components (Jerabkova et al. 2011; Thomas et al. 2000), but those positive responses gradually diminished over a longer term as a result of removal of residue materials and consequent nutrient depletion (Kimmins 1997). Sapling growth responses to logging residue removal varied among different tree species over time (Barrett et al. 2016), which suggests that long-term experiments are needed to capture those possible long-term dynamic responses (Eisenbies et al. 2009; Kurth et al. 2014; Thiffault et al. 2011). However, only a few long-term experiment studies (about 20 years or longer) have been reported in the literature (e.g., Jurevics et al. 2016; Thiffault et al. 2011; Vanguelova et al. 2010). To fill this gap as well as to assess the mechanisms with which the positive relations between logging residue loadings and tree growth can be better understood, we collected data on soil nutrients at several points of time during the 19-year study period and analyzed their relationships to the loading levels and tree growth. In addition, data on foliar nutrients were also collected and their relationships with soil nutrients were analyzed in this study as foliar nutrients may provide useful and diagnostic information about soil nutrients (Carter and Brockley 1990).

Lodgepole pine (Pinus contorta Doug. ex Loud.) forests distributed widely throughout North America, and the tree species is considered a fire-adapted and shade-intolerant tree species (Burns and Honkala 1990). Numerous studies have focused on lodgepole pine emergence, growth, nutrient dynamics and their responses to climate, and natural or human disturbance (Cirelli et al. 2016; MacLachlan et al. 2017; Nelson et al. 2016; Turner et al. 2016). There are two harvesting methods applied widely in British Columbia (BC), Canada, including whole-tree harvesting (WTH) and stemonly harvesting ( $\mathrm{SOH})$. The key difference between WTH and $\mathrm{SOH}$ is whether crown materials (branches, twigs, and 
foliage) are removed with stems or left as logging residues (Bélanger et al. 2003; Thiffault et al. 2011). We hypothesized that (1) the responses of tree growth to the logging residue loading levels would be positive and dynamic over the long term; and (2) the positive responses of tree growth are related to improvement of soil nutrients as a result of logging residue loadings. We tested those hypotheses using our long-term (19 years) field experiment established in a lodgepole pine forest in the BC interior of Canada in 1996.

\section{Materials and methods}

\subsection{Study site}

The experiment was conducted near Satah Mountain $\left(52^{\circ} 28^{\prime}\right.$ $\mathrm{N}, 124^{\circ} 43^{\prime} \mathrm{W}$ ), located about $110 \mathrm{~km}$ northwest of Alexis Creek, west-central British Columbia, Canada. The region has a mean annual precipitation which varies between 300 and $800 \mathrm{~mm}$, and much of it comes as snow during the winter. The mean annual temperature is $1.3^{\circ} \mathrm{C}$, and the snow covers usually from November to April. Severe frosts as well as frequent droughts are common throughout the summer (Sagar et al. 2005; Sagar and Waterhouse 2015). Soils are Gray Luvisols with a sandy loam texture on glaciofluvial parent material (Berch et al. 2010). The study is located in the Sub-Boreal Pine Spruce and Montane Spruce biogeoclimatic zones.

\subsection{Experimental design}

The study is part of the Itcha-Ilgachuz Project, which aimed to test the effects of various silvicultural systems on forest functions and processes (Sagar and Waterhouse 2015). The experiment is an update of our previous study with further extension of the 10-year-long growth data. Briefly, four experimental treatments were randomly arranged into five blocks which are over 100 ha each. Four $20 \mathrm{~m} \times 20$-m plots were established in each block. The treatments previously described by Wei et al. (2012), were (1) removal of all logging residues (N, $0 \mathrm{mg} \mathrm{ha}{ }^{-1}$ ), removed manually; (2) logging residue loading similar to whole-tree harvesting residuals left on site (W, 35$45 \mathrm{mg} \mathrm{ha}^{-1}$ ); (3) logging residue loading similar to stem-only harvesting residuals left on site ( $\left.\mathrm{S}, 60-70 \mathrm{mg} \mathrm{ha}^{-1}\right)$; and (4) logging residue loading similar to double that of stem-only harvesting and similar to disease and insects killed stands (D, 100-120 $\mathrm{m} \mathrm{ha}^{-1}$ ). Additional debris was spread uniformly by hand. The N, W, S, and D treatments were randomly assigned to the plots within each block, and no further measurements of the debris weight change over time were made (Wei et al. 2012).

\subsection{Measurement of sapling growth}

Basal diameter and height of seedlings in each plot were measured 10 times (years 1, 2, 3, 5, 6, 9, 10, 11, 14, and 19) over the study period (1996 to 2015). Since the measurements were conducted at different intervals, the annual average growths for diameter (basal location) and height were estimated from the differences between two consecutive measurements divided by associated time intervals. We replaced the dead saplings with new ones due to a severe early spring frost in July 1997, ranging from 5 to $20 \%$ among the treatment blocks. To ensure consistent comparison, the 1997 replacement seedlings were not included in the statistical analysis, even though they were measured in subsequent years. The present study examines the net increments of basal diameter and height during the 19year-long growth, which is different with our previous paper that reported the basal diameter and height in the first 10 years (Wei et al. 2012).

\subsection{Analysis of soil and foliage samples}

In order to investigate the relationships between soil nutrients and tree growth, three mineral soil cores per plot were combined to form one composite soil sample per sampling year in 2001, 2006, and 2015. All soil samples were collected from 0 to $20-\mathrm{cm}$ mineral layer after removing the humic litter and organic horizon. Two composite foliage samples per plot were also collected in the summer of 2015 to test the correlations between soil nutrients and foliage chemistry. Green needles, which were identified by eyes, were sampled in the four cardinal directions, i.e., east, south, west, and north of the sampled trees. All soil samples were analyzed for total carbon (C), total nitrogen $(\mathrm{N})$, available phosphorus $(\mathrm{P})$, and exchangeable cations $(\mathrm{Ca}, \mathrm{K}, \mathrm{Mg})$. Foliage samples were analyzed for $\mathrm{N}, \mathrm{P}, \mathrm{Ca}, \mathrm{K}, \mathrm{Mg}, \mathrm{Zn}, \mathrm{Cu}, \mathrm{B}$, and sulfur (S). Soil and foliage samples were analyzed at the chemistry laboratory of the British Columbia Ministry of Forests, Lands and Natural Resource Operations following their standard analytical protocols (Carter and Gregorich 2006). C and N were analyzed by elemental analyzer (Thermo Electron Corporation, MA, USA), metal elements mentioned above were analyzed by inductively coupled plasma mass spectrometer (ICP-MS, Agilent, Santa Clara, CA, USA), and available P was measured with a UV-visible spectrophotometer after extraction with acid-ammonium fluoride solution. All data have been deposited into the website Dryad (Wu et al. 2020).

\subsection{Statistical analysis}

Data on annual net tree growth (diameter and height) were used for data analysis. The treatments $(\mathrm{N}, \mathrm{W}, \mathrm{S}$, and $\mathrm{D})$ and year of measurement were fixed factors. Seedling diameter and height were tested by analysis of variance using a mixed 
model with repeated measures. The initial seedling size was used as covariate in the statistical analysis. Effects of treatments on soil nutrients in 2006 and 2015 were also analyzed using the same method. Pearson correlations were used to detect the relationships between soil nutrients, foliage nutrients, and tree growth during different stand ages. Homogeneity and normality of data sets were checked before conducting analysis. Differences of treatment means in each sampling interval were compared using a Tukey's test. Significance was set at $P<0.05$. All statistical analyses were performed with R version R 3.3.2 (R Core Team 2016).

\section{Results}

Treatment $\mathrm{N}$ displayed the lowest diameter growth while treatment $\mathrm{D}$ had significantly positive effects on diameter increment of lodgepole pine seedlings since the third year as compared with the other three treatments (Fig. 1a and Table 1). Diameter growth was not significantly different among treatments $\mathrm{N}, \mathrm{S}$, and $\mathrm{W}$ until the 11th and subsequent years, when diameter growth in treatment $\mathrm{S}$ was significantly higher than that in treatment $\mathrm{N}$ (Table 1).

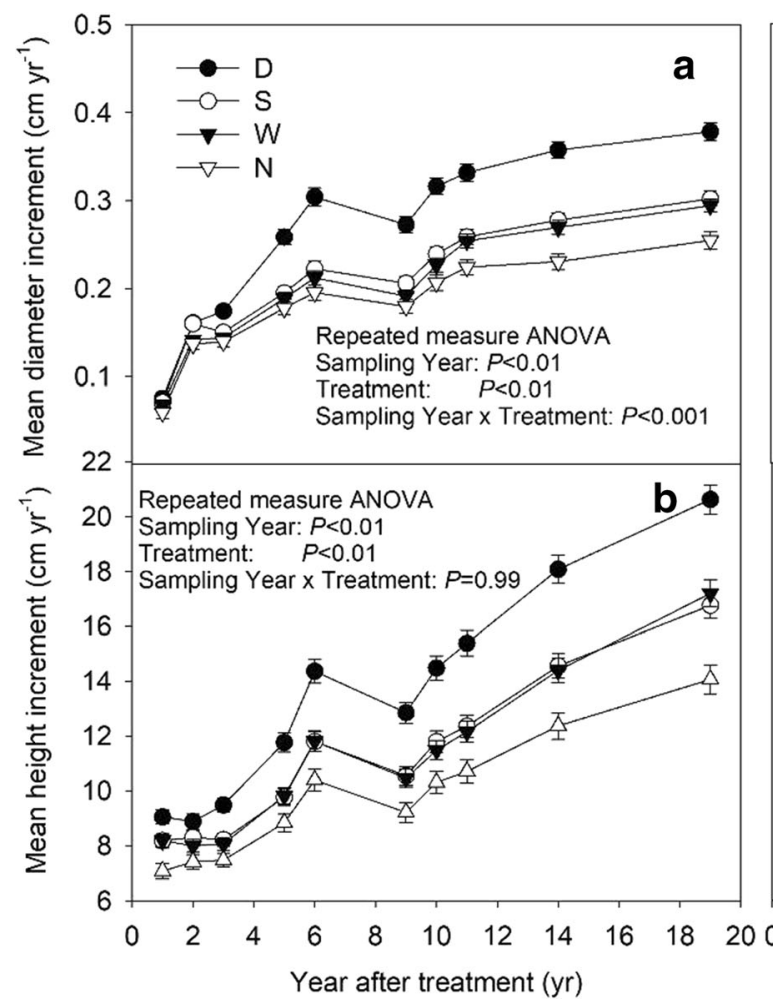

Fig. 1 Annual mean diameter growth (a), mean height growth (b) dynamics, annual mean diameter (c), and mean height $(\mathbf{d})$ in four logging residue loading treatments over the 19 -year study period. The $\mathrm{N}, \mathrm{W}, \mathrm{S}$, and D treatments were (1) removal of all organic matter $(\mathrm{N})$, (2) logging residue loading similar to whole-tree harvesting residuals left
Table 1 Results of one-way ANOVA concerning the differences in diameter growth and height growth among the four treatments by using Tukey's test.

\begin{tabular}{lllllllllll} 
& \multicolumn{1}{c}{ Year } & & & & & & & & \\
\cline { 2 - 8 } & 1 & 2 & 3 & 5 & 6 & 9 & 10 & 11 & 14 & 19
\end{tabular}

\begin{tabular}{llllllllllll}
\hline Diameter & N & a & a & a & a & a & a & a & a & a & a \\
& W & a & ab & a & a & a & a & a & ab & b & b \\
& S & a & b & a & a & a & a & a & b & b & b \\
\multirow{5}{*}{ Height } & D & a & b & b & b & b & b & b & c & c & c \\
& N & a & a & a & a & a & a & a & a & a & a \\
& W & b & ab & a & a & a & a & a & ab & b & b \\
& S & b & ab & a & a & a & a & a & b & b & b \\
& D & b & b & b & b & b & b & b & c & c & c \\
\hline
\end{tabular}

The different letters in the same column mean significant difference in the sampling year after treatments. The mean difference is significant at the 0.05 level, $n=5$

Tree height growth responded more quickly than diameter growth as the difference in height growth between treatments $\mathrm{D}$ and $\mathrm{N}$ was detected 1 year after treatment (Fig. $1 \mathrm{~b}$ and Table 1). Treatment $\mathrm{D}$ had the largest height growth, while

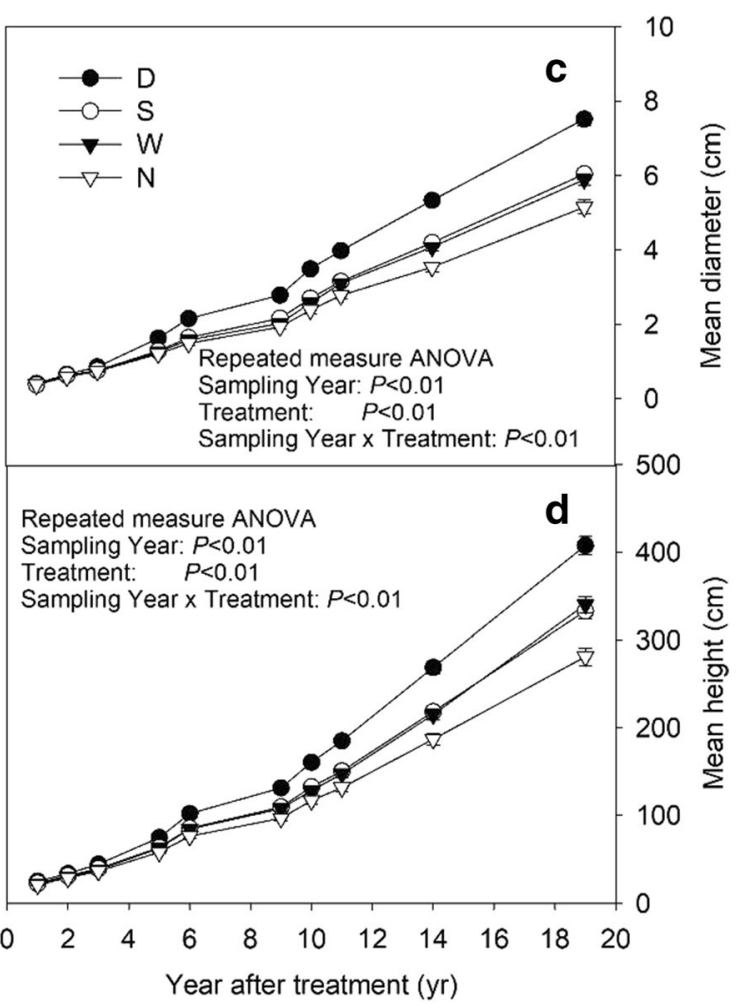

o site (W), (3) logging residue loading similar to stem-only harvesting residuals left on site (S), and (4) logging residue loading double that of stem-only harvesting and similar to disease and insects killed stands (d), respectively. The $P$ values were from the repeated measure ANOVA that concerns sampling year, residue loading treatments, and their interactions 
Table 2 Mean values of soil nutrients in three sampling years (2001, 2006, and 2015, respectively).

\begin{tabular}{lllllllll}
\hline & & Total C $(\%)$ & Total N $(\%)$ & C:N & Avail. P $(\mathrm{mg} / \mathrm{kg})$ & Exch. K (cmol+/kg) & Exch. Ca (cmol+/kg) & Exch. Mg (cmol+/kg) \\
\hline 2001 & N & $1.90 \pm 0.25$ & $0.789 \pm 0.01$ & $23.95 \pm 1.15$ & $36.41 \pm 6.23$ & $0.30 \pm 0.05$ & $3.14 \pm 0.82$ & $0.96 \pm 0.36$ \\
& W & $2.17 \pm 0.13$ & $0.885 \pm 0.01$ & $24.61 \pm 0.0 .45$ & $36.23 \pm 6.71$ & $0.33 \pm 0.06$ & $3.32 \pm 0.60$ & $0.91 \pm 0.20$ \\
& S & $2.05 \pm 0.13$ & $0.809 \pm 0.01$ & $25.36 \pm 0.50$ & $37.91 \pm 5.55$ & $0.39 \pm 0.07$ & $3.64 \pm 0.83$ & $0.95 \pm 0.27$ \\
& D & $2.41 \pm 1.15$ & $0.993 \pm 0.01$ & $24.36 \pm 0.14$ & $45.35 \pm 10.50$ & $0.47 \pm 0.09$ & $4.15 \pm 0.93$ & $0.94 \pm 0.24$ \\
2006 & N & $1.82 \pm 0.29$ & $0.692 \pm 0.01$ & $25.20 \pm 1.12$ & $38.48 \pm 7.83$ & $0.28 \pm 0.06$ & $2.61 \pm 0.73$ & $0.87 \pm 0.32$ \\
& W & $2.01 \pm 0.16$ & $0.723 \pm 0.01$ & $27.89 \pm 1.33$ & $41.96 \pm 5.18$ & $0.34 \pm 0.02$ & $3.40 \pm 0.85$ & $1.09 \pm 0.25$ \\
& S & $2.04 \pm 0.21$ & $0.740 \pm 0.01$ & $26.99 \pm 1.42$ & $37.71 \pm 1.79$ & $0.30 \pm 0.08$ & $2.93 \pm 1.02$ & $0.75 \pm 0.25$ \\
& D & $1.99 \pm 0.32$ & $0.740 \pm 0.01$ & $27.20 \pm 1.25$ & $42.71 \pm 8.02$ & $0.35 \pm 0.06$ & $2.93 \pm 0.56$ & $0.97 \pm 0.23$ \\
& N & $1.49 \pm 0.24$ & $0.608 \pm 0.01$ & $25.12 \pm 1.59$ & $41.03 \pm 9.91$ & $0.43 \pm 0.08$ & $3.53 \pm 0.87$ & $1.11 \pm 0.30$ \\
& W & $1.73 \pm 0.22$ & $0.629 \pm 0.01$ & $26.40 \pm 0.70$ & $46.71 \pm 6.54$ & $0.29 \pm 0.05$ & $2.80 \pm 0.38$ & $0.86 \pm 0.12$ \\
& S & $1.82 \pm 0.22$ & $0.700 \pm 0.01$ & $26.29 \pm 0.83$ & $47.23 \pm 4.43$ & $0.26 \pm 0.06$ & $3.14 \pm 0.90$ & $0.88 \pm 0.30$ \\
D & $2.03 \pm 0.25$ & $0.786 \pm 0.01$ & $25.85 \pm 1.22$ & $50.74 \pm 13.10$ & $0.33 \pm 0.05$ & $2.97 \pm 0.73$ & $1.03 \pm 0.28$ \\
\hline
\end{tabular}

"Avail." means "available"; "Exch." means "exchangeable"

Total $C$, total carbon in soil; Total $N$, total soil nitrogen; $C: N$, ratio of soil organic carbon to total nitrogen

Values are the means $\pm \mathrm{SE}, n=5$

no significant differences were detected among treatments $\mathrm{N}$, $\mathrm{S}$, and $\mathrm{W}$ until the 11th and subsequent years, when the height growth in treatment $\mathrm{S}$ became significantly larger than that in treatment $\mathrm{N}$. The difference in height growth between treatments $\mathrm{W}$ and $\mathrm{N}$ was not significant until the 14th and subsequent years (Table 1). Significant interactions between sampling year and logging residue loading treatments were found for diameter growth (Fig. 1).

Sampling year but not logging residue loading had significant effects on soil nutrient contents (Tables 2 and 3 ). The logging residue loading treatments did not significantly affect foliar nutrients except boron (B). Foliar B content from the treatment $\mathrm{D}$ was significantly higher than that found in treatments $\mathrm{N}$ and $\mathrm{W}$ (Fig. 2). Foliar nutrients $\mathrm{N}$ and $\mathrm{P}$ were significantly related to soil nutrients, while $\mathrm{K}, \mathrm{Ca}$, and $\mathrm{Mg}$ were not (Fig. 3). Foliar $\mathrm{SO}_{4}-\mathrm{S}$ and $\mathrm{Ca}$ in 2015 had a significant but negative relation with the diameter growth in the period of 2010-2015, respectively (Annex Table 6).
There was no significant correlation between soil nutrients in 2006 (year 10) and the diameter growth in the period of 2001-2006 (Table 4). Soil C, N, C:N, and available P collected in 2015 were positively related to the diameter growth in the periods 2010-2015. All soil nutrients except soil $\mathrm{N}$ in 2015 positively related to the height growth in the period of 2010-2015 (Table 5). Soil C:N positively related with the height growth in the periods 2010-2015 (Table 5).

\section{Discussion}

Our results indicate that sapling growth as measured by diameter and height increased with logging residue loading over the 19-year study period in young lodgepole pine forests, which supports the first hypothesis. Treatment $\mathrm{D}$, the highest residue loading treatment, had the greatest and earliest positive effects on seedling growth; while treatment $\mathrm{N}$, the lowest
Table $3 P$ values for repeated measures ANOVA concerning the effects of sampling year (SY), logging residue loading treatments $(\mathrm{T})$, and their interactions on soil nutrients after 5 years (2001), 10 years (2006), and 19 years (2015).

\begin{tabular}{|c|c|c|c|c|c|c|c|}
\hline & \multicolumn{7}{|c|}{ Soil nutrients } \\
\hline & $\mathrm{SOC}$ & $\mathrm{TN}$ & $\mathrm{C}: \mathrm{N}$ & Avail. P & Exch. K & Exch. $\mathrm{Ca}$ & Exch. Mg \\
\hline SY & 0.04 & $<0.001$ & 0.001 & 0.031 & 0.046 & 0.009 & 0.792 \\
\hline $\mathrm{T}$ & 0.506 & 0.554 & 0.562 & 0.887 & 0.84 & 0.996 & 0.984 \\
\hline $\mathrm{SY} \times \mathrm{T}$ & 0.762 & 0.558 & 0.876 & 0.926 & 0.001 & 0.037 & 0.299 \\
\hline 2001 & $\mathrm{a}$ & $\mathrm{a}$ & $\mathrm{b}$ & $\mathrm{b}$ & $\mathrm{a}$ & $\mathrm{a}$ & $\mathrm{a}$ \\
\hline 2006 & $\mathrm{a}$ & $\mathrm{b}$ & $\mathrm{a}$ & $a b$ & $\mathrm{~b}$ & $\mathrm{~b}$ & $\mathrm{a}$ \\
\hline 2015 & $\mathrm{~b}$ & $\mathrm{~b}$ & $\mathrm{a}$ & $\mathrm{a}$ & $\mathrm{b}$ & $\mathrm{b}$ & $\mathrm{a}$ \\
\hline
\end{tabular}

The comparisons among the three sampling years were conducted using Tukey's test. The different letters in the same column mean significant difference among the sampling years after treatments. The mean difference is significant at the 0.05 level, $n=5$ 


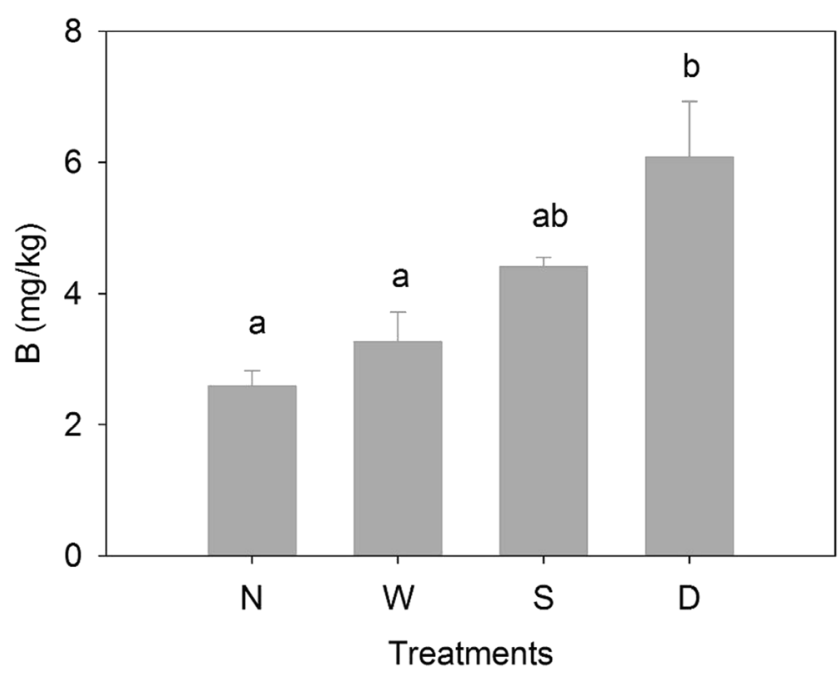

Fig. 2 The difference in foliar boron (B) contents after the 19-year period between four logging residue loading treatments. Values are the means \pm $\mathrm{SE}$ of five plots. The different letters in the same column mean significant difference based on ANOVA and Tukey's test $(P<0.05)$

residue loading, had the lowest seedling growth response. Treatment $\mathrm{D}$, in comparison with treatment $\mathrm{N}$, had a significantly positive effect in year 2 and about 1.6-fold higher by the end of the study period. Our results are consistent with several other studies (Harrington et al. 2013; Vanguelova et al. 2010). For example, Harrington et al. (2013) found that the remaining both $40 \%$ and $80 \%$ of logging debris facilitated growth of Douglas-fir compared with removal of all logging debris. The positive and dynamic relationships between logging residue loading and seedling growth from our study clearly suggest that retention of logging residue has longterm effects on seedling growth, and the long-term experiments may be the suitable way to reveal such dynamic relationships.

The significant differences in sapling growth between treatment $\mathrm{D}$ and treatments $\mathrm{S}$ and $\mathrm{W}$ suggest that enhanced residue loading levels higher than those from treatments $\mathrm{S}$ and $\mathrm{W}$ (equivalent loading levels from $\mathrm{SOH}$ and WTH harvesting methods, respectively) can further significantly improve sapling growth in the sub-boreal forests. However, the loading level from treatment $\mathrm{D}$ is higher than what current harvesting methods (SOH and WTH) can produce in the study region. The positive effects from higher residue loading indicate that the residue loading from natural disturbance may confer a longer term positive benefit to sapling growth than from normal timber harvesting, and this should be recognized when designing forest management strategies at the landscape scale. We also point out that large amount of logging residue loading would increase fire hazard and enhance $\mathrm{N}$ leaching from sites, which could then negatively affect the forest ecosystems.

Our result indicated that tree growth was not significantly different between treatments $\mathrm{W}$ and $\mathrm{S}$ during the 19-year study. The similar sapling growth of these two logging residue loading methods may indicate that choice of harvesting system should be based on other factors in addition to site productivity in our study area (Waterhouse et al. 2010). This result is consistent with the simulation result from Wei et al. (2003) where there was no much difference in long-term site productivity between WTH and $\mathrm{SOH}$ (equivalent to our treatments $\mathrm{W}$ and $\mathrm{S}$, respectively) in lodgepole pine forests in the same region. It is also consistent with the results from the experiment involving residue removal in 14 experiments in Canada (Morris et al. 2019). However, the lack of significant difference in tree growth between $\mathrm{S}$ and $\mathrm{W}$ treatments may be due to the following reasons. The first one is that the responses of tree growth and soil nutrients may be relatively resilient to logging residue loading, and consequently, the gap between the loading levels of W and S might not be sufficiently large to lead to the so-called statistical difference, despite the fact that the logging residue loading levels in both $\mathrm{S}$ and $\mathrm{W}$ in our study are larger than annual averaged logging residue $\left(26 \mathrm{mg} \mathrm{ha}^{-1}\right.$ ) in Canadian forests (Barrette et al. 2018). The second is that a large portion of the logging residue in our study is coarse woody debris (51\% and $70 \%$ for S and W, respectively) in our experiment, which may play a limited role in soil nutrient capitals due to slow decay in their early decay stage following disturbance (Herrero et al. 2010; Wei et al. 1997). Whether the amount of coarse woody debris in our experiments would drive the different responses between $\mathrm{S}$ and $\mathrm{W}$ in the future requires a longer monitoring. Nevertheless, several other long-term (23-31 years long) studies indicated that tree growth in $\mathrm{SOH}$ was larger than that in WTH in Norway spruce, Sikta spruce, Chinese fir, and Scots pine forests (Egnell 2011; Nambiar and Kallio 2008; Walmsley et al. 2009). All these results suggest that the effects of tree species and their harvesting intensities on tree growth are complex, which may require a much longer term monitoring before any general conclusions can be derived.

Our study detected dynamic correlations between soil nutrients and sapling growth, which partially supported our second hypothesis. There were few correlations between soil nutrients and tree diameter and height growth in the early stage (e.g., 2006), while more correlations were detected in the later stage (e.g., 2015). The significant relationships were detected between some soil nutrients in 2015 and tree growth in the period of 2010-2015. Like the dynamic responses of sapling growth to different residue treatments, the relationships between soil nutrients and sapling growth also varied with treatment time. The dynamic relationships between logging residue loading and tree growth, and between soil nutrients and tree growth, have also been shown to be significant by Sanborn (2001), who reported that logging residue loading affects sapling growth through their influence on soil nutrition.

To our surprise, the residue loading treatments did not significantly affect soil nutrient contents, which did not fully support the second hypothesis. Here are our explanations. 

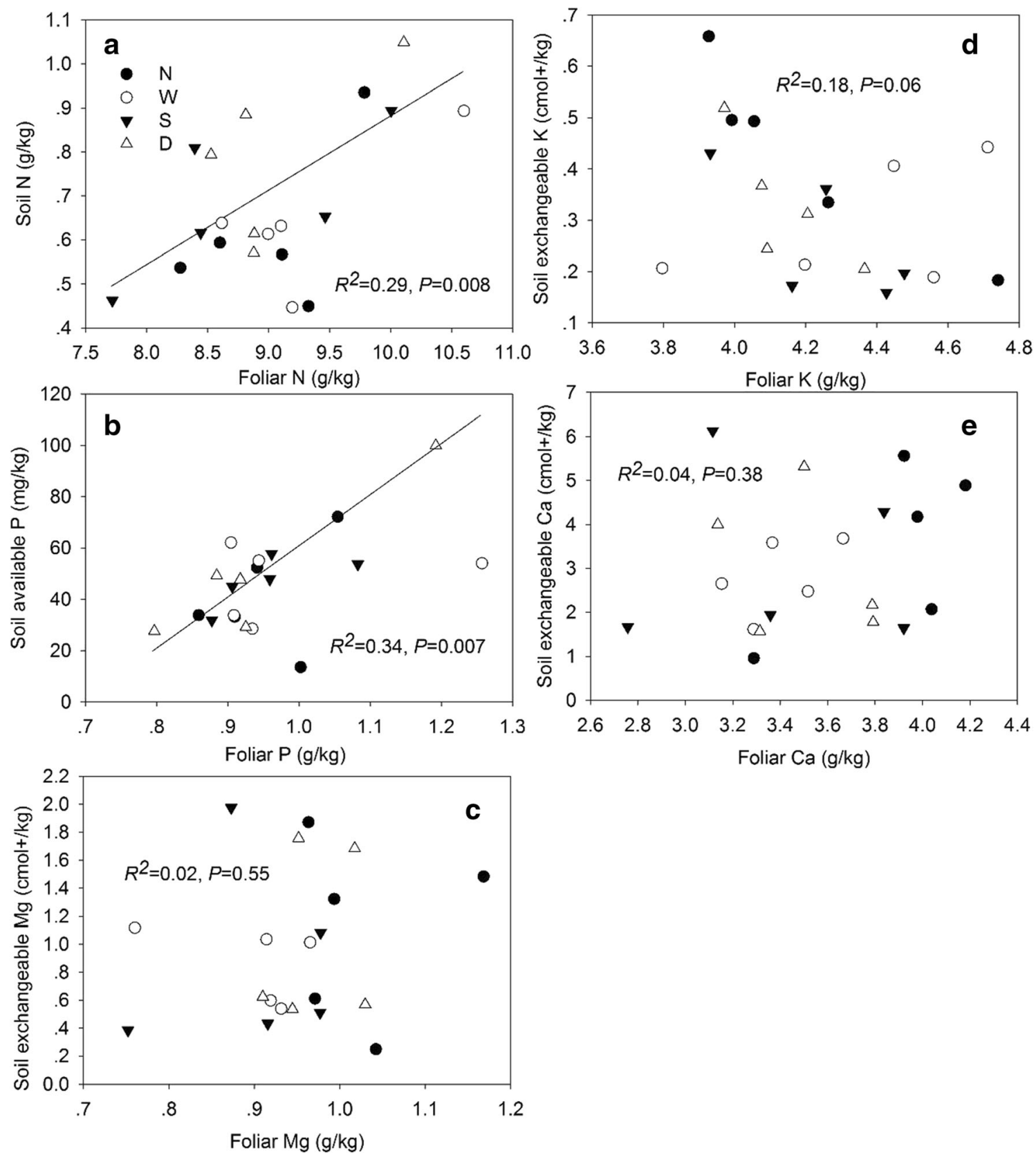

Fig. 3 Relationships between soil and foliar nutrients after the 19-year organic residue loading treatments

Firstly, the mineral soils in the study region are highly resilient to soil managements. This is consistent with the results by Sanchez et al. (2006) and Kishchuk et al. (2014), who found that soil nutrients were not significantly changed after land management treatments (not even by the extreme treatment), and concluded that the soils are highly resilient to forest management perturbations. The possible reason is that the soils in the study region are relatively young and have limited capacity to store nutrients. Secondly, because of the limited nutrient storage capacity in the soils, nutrient fluxes released from logging residue loadings might play a more important role in promoting tree growth than the stored nutrients in the mineral soil pools (Reid et al. 2015). This is clearly evidenced from more correlations detected in the latter stage of the study period as more coarse woody debris likely releases more nutrients. It is also supported by our data. For example, treatment D has much higher loading levels than treatment $\mathrm{N}$ so that treatment $\mathrm{D}$ has more nutrient fluxes and consequently greater tree growths. While forests normally rely on nutrient storage in mineral soil pools, some forests may be dependent upon nutrient fluxes or nutrient cycling (Jurevics et al. 2016; Smolander et al. 2019). For example, Grau et al. (2017) found that nutrient cycling mechanisms other than the direct absorption from mineral soil may control forest structure and 
Table 4 Pearson correlations between soil nutrients and diameter growth with $r$ and $p$ values.

\begin{tabular}{lccccc}
\hline Diameter & \multicolumn{2}{l}{$2001-2006$} & & & \multicolumn{2}{l}{$2010-2015$} \\
\cline { 2 - 3 } \cline { 5 - 6 } Soil & 2006 & & & 2015 & \\
\cline { 2 - 3 } \cline { 5 - 6 } & $r$ & & & & $p$ \\
\hline Total C & -0.06 & 0.79 & & 0.75 & $<0.001$ \\
Total N & -0.17 & 0.46 & & 0.63 & 0.002 \\
C:N & 0.39 & 0.091 & & 0.56 & 0.009 \\
Avail. P & 0.13 & 0.60 & & 0.73 & $<0.001$ \\
Exch. K & -0.01 & 0.97 & & -0.62 & 0.004 \\
Exch. Ca & -0.15 & 0.52 & & -0.63 & 0.003 \\
Exch. Mg & -0.20 & 0.39 & -0.63 & 0.003 \\
\hline
\end{tabular}

"Avail." means "available"; "Exch." means "exchangeable"

Total $C$, total carbon in soil; Total $N$, total soil nitrogen; $C: N$, ratio of soil organic carbon to total nitrogen. The soil data were collected in 2006 and 2015 , while the diameter growth data were estimated for the annual average increment of the measuring periods of 2001-2006 and 2010-2015.

The data were the values from each plot of four treatments, $n=5$

dynamics in poor Amazonian soils. Based on the above reasons, it is possible that the increasing role of nutrient fluxes in tree growth in the latter stage of the study period further enlarged the difference in tree growth so that the correlations between nutrients and tree growth became statistically significant.

Our study showed that nutrients including nitrogen and phosphorus in soil and foliar samples, collected in 2015, were significantly related, and this has also been shown in the study

Table 5 Pearson correlations between soil nutrients and height growth with $r$ and $p$ values.

\begin{tabular}{lccccr}
\hline Height & \multicolumn{2}{l}{$2001-2006$} & & \multicolumn{2}{l}{$2010-2015$} \\
\cline { 2 - 3 } \cline { 5 - 6 } Soil & 2006 & & & 2015 & \\
\cline { 2 - 3 } \cline { 5 - 6 } & $r$ & & & & $p$ \\
\hline Total C & -0.29 & 0.22 & & 0.559 & 0.01 \\
Total N & -0.39 & 0.09 & & 0.38 & 0.10 \\
C:N & 0.38 & 0.10 & & 0.687 & 0.001 \\
Avail. P & 0.005 & 0.98 & & 0.63 & 0.002 \\
Exch. K & 0.02 & 0.94 & & -0.57 & 0.008 \\
Exch. Ca & -0.02 & 0.92 & & -0.52 & 0.02 \\
Exch. Mg & -0.06 & 0.81 & -0.55 & 0.01 \\
\hline
\end{tabular}

"Avail." means "available"; "Exch.” means "exchangeable"

Total $C$, total carbon in soil; Total $N$, total soil nitrogen; $C: N$, ratio of soil organic carbon to total nitrogen. The soil data were collected in 2006 and 2015 , while the height data were estimated for the annual average increment of the measuring periods of 2001-2006 and 2010-2015. The data were the values from each plot of four treatments, $n=5$ by Fan et al. (2015). However, other nutrients such as $\mathrm{Ca}, \mathrm{Mg}$, and $\mathrm{K}$ did not show any statistical relationships between soil and foliage samples in our study. We speculate that the top 20$\mathrm{cm}$ mineral soil layer does not represent the nutrient condition of whole soil and the resorption may have had different patterns among nutrients (Sterner and Elser 2002), which resulted in inconsistent outputs. Retranslocation of N, P, and K is usual from old leaves to new leaves, but the resorption of $\mathrm{Mg}$ and $\mathrm{Ca}$ may show a confounded pattern (Fife et al. 2008). In addition, our results indicated that there were few correlations between foliar nutrients and seedling growth and between foliar nutrients and logging residue loading. We only found that foliar boron increased with the amount of organic matter added. Boron is important for primary growth and physiological functions of vegetation (Lehto et al. 2010). According to Carter and Brockley (1990), boron deficiency is common in soils in the study region. A larger amount of logging residue loading would potentially result in more availability of nutrients, i.e., boron for tree growth, which partially supported that the highest loading level (D) promoted nutrient flux and tree growth than treatment $\mathrm{N}$ did.

\section{Conclusions}

Based on our long-term experiment, we have the following conclusions. Firstly, the amounts of logging residue loading had significant and positive effects on tree growth of lodgepole pine, and the largest residue loading produced the greatest growth response. Secondly, the lack of significant responses of soil nutrients to logging residue loadings clearly demonstrated highly resilient soils in the study region. The correlations between some soil nutrients (i.e., soil available $\mathrm{P}$ and exchangeable $\mathrm{K}, \mathrm{Ca}$, and $\mathrm{Mg}$ ) and tree growth became significant after year 10 . Those results suggested that nutrient fluxes from logging residue loadings might play a more important role in tree growth, which requires further investigations. Thirdly, the lack of difference in sapling growth between stem-only harvesting and whole-tree harvesting treatments suggests selection of either harvesting method may not cause any different effects on tree growth in young lodgepole forests. All above conclusions can have important implications for designing of nature-based management practices for sustainable forest productivity. However, a suitable amount of logging residue loading should be designed in the context of broader management objectives including protection of wildlife habitat and biodiversity, bio-energy production, and reduction of fire and disease hazards.

Acknowledgments We thank the editors and two anonymous reviewers for their insightful comments. We are also grateful to Qiang Li and Wei Liu for their assistance in our field work. 
Funding information This research was supported by the funding of "Using GIS and Time Series Analysis to Evaluate Impacts of LargeScale Salvage Logging on Hydrology in the BC Interior" and by Yunnan University (No. C176210103).

Data availability The datasets generated and/or analyzed during the current study are available in the Dryad repository, https://doi.org/10.5061/ dryad.51c59zw4z.

\section{Compliance with ethical standards}

Conflict of interest The authors declare that they have no competing interests.

\section{Annex}

Table 6 Pearson correlations between foliar nutrients and diameter and height growths with $r$ and $p$ values. The foliage data were collected in 2015, while the diameter and height growth data were collected for the periods of 2010-2015

\begin{tabular}{|c|c|c|c|c|}
\hline & \multicolumn{2}{|c|}{ Diameter } & \multicolumn{2}{|l|}{ Height } \\
\hline & $r$ & $p$ & $r$ & $p$ \\
\hline $\mathrm{Al}$ & -0.35 & 0.14 & -0.19 & 0.43 \\
\hline B & 0.16 & 0.51 & 0.15 & 0.53 \\
\hline $\mathrm{Ca}$ & -0.28 & 0.24 & -0.47 & 0.04 \\
\hline $\mathrm{K}$ & -0.19 & 0.43 & 0.18 & 0.45 \\
\hline $\mathrm{Mg}$ & -0.18 & 0.45 & -0.20 & 0.39 \\
\hline $\mathrm{Mn}$ & -0.23 & 0.33 & -0.28 & 0.23 \\
\hline $\mathrm{Na}$ & -0.03 & 0.89 & -0.06 & 0.81 \\
\hline $\mathrm{N}$ & 0.08 & 0.75 & 0.25 & 0.28 \\
\hline $\mathrm{C}: \mathrm{N}$ & -0.10 & 0.69 & -0.25 & 0.28 \\
\hline $\mathrm{P}$ & -0.10 & 0.68 & 0.16 & 0.50 \\
\hline S & -0.42 & 0.07 & -0.09 & 0.69 \\
\hline $\mathrm{SO}_{4}-\mathrm{S}$ & -0.54 & 0.02 & -0.34 & 0.14 \\
\hline $\mathrm{Zn}$ & 0.12 & 0.62 & -0.02 & 0.92 \\
\hline $\mathrm{Cu}$ & -0.37 & 0.11 & -0.12 & 0.60 \\
\hline $\mathrm{Fe}$ & -0.33 & 0.16 & -0.21 & 0.37 \\
\hline
\end{tabular}

\section{References}

Barrett SM, Aust WM, Bolding MC, Lakel WA, Munsell JF (2016) Estimated erosion, ground cover, and best management practices audit details for postharvest evaluations of biomass and conventional clearcut harvests. J Forest 114:9-16

Barrette J, Paré D, Manka F, Guindon L, Bernier P, Titus B (2018) Forecasting the spatial distribution of logging residues across the Canadian managed forest. Can J For Res 48:1470-1481

Bélanger N, Paré D, Yamasaki SH (2003) The soil acid base status of boreal black spruce stands after whole-tree and stem-only harvesting. Can J For Res 33:1874-1879
Berch S, Curran M, Chapman WK, Dube S, Hope G, Kabzems R, Kranabetter JM, Hannam KD (2010) Long-term soil productivity study (LTSP): the effects of soil compaction and organic matter retention on long-term soil productivity. BC Ministry of Forest and Range, Victoria, BC.

Bradford MA, Warren IIJ, Baldrian P, Crowther TW, Maynard DS, Oldfield E, Wieder WR, Wood SA, King JR (2014) Climate fails to predict wood decomposition at regional scales. Nat Clim Chang 4:625-630

Bradford MA, Berg B, Maynard DS, Wieder WR, Wood SA (2016) Understanding the dominant controls on litter decomposition. J Ecol 104:229-238

Burns RM, Honkala BH (1990) Silvics of North America. Volume 1. Conifers. Agriculture Handbook (Washington), USA.

Carter RE, Brockley RO (1990) Boron deficiencies in British Columbia: diagnosis and treatment evaluation. Forest Ecol Manag 37:83-94

Carter M, Gregorich E (2006) Soil sampling and methods of analysis, Second edn. CRC Press, Canada

Cirelli D, Vinge T, Lieffers VJ (2016) Assisted lodgepole pine regeneration on reclamation sites using logging slash as both a mulch and natural seed source. Can J For Res 46:1132-1137

Clarke N, Gundersen P, Jönsson-Belyazid U, Kjønaas OJ, Persson T, Sigurdsson BD, Stupak I, Vesterdal L (2015) Influence of different tree-harvesting intensities on forest soil carbon stocks in boreal and northern temperate forest ecosystems. Forest Ecol Manag 351:9-19

Egnell G (2011) Is the productivity decline in Norway spruce following whole-tree harvesting in the final felling in boreal Sweden permanent or temporary? Forest Ecol Manag 261:148-153

Egnell G (2017) A review of Nordic trials studying effects of biomass harvest intensity on subsequent forest production. Forest Ecol Manag 383:27-36

Eisenbies MH, Burger JA, Aust WM, Patterson SC (2005) Soil physical disturbance and logging residue effects on changes in soil productivity in five-year-old pine plantations. Soil Sci Soc Am J 69:18331843

Eisenbies MH, Vance ED, Aust WM, Seiler JR (2009) Intensive utilization of harvest residues in southern pine plantations: quantities available and implications for nutrient budgets and sustainable site productivity. BioEnerg Res 2:90-98

Fan H, Wu J, Liu W, Yuan Y, Hu L, Cai Q (2015) Linkages of plant and soil C:N:P stoichiometry and their relationships to forest growth in subtropical plantations. Plant Soil 392:127-138

Fife D, Nambiar E, Saur E (2008) Retranslocation of foliar nutrients in evergreen tree species planted in a Mediterranean environment. Tree Physiol 28:187-196

Grau O, Peñuelas J, Ferry B, Freycon V, Blanc L, Desprez M, Baraloto C, Chave J, Descroix L, Dourdain A, Guitet S, Janssens IA, Sardans J, Hérault B (2017) Nutrient-cycling mechanisms other than the direct absorption from soil may control forest structure and dynamics in poor Amazonian soils. Sci Rep 7:45017. https://doi.org/10.1038/ srep45017

Harmon ME, Bond-Lamberty B, Tang J, Vargas R (2011) Heterotrophic respiration in disturbed forests: a review with examples from North America. J Geophys Res Biogeosci 116:G00K04

Harrington TB, Slesak RA, Schoenholtz SH (2013) Variation in logging debris cover influences competitor abundance, resource availability, and early growth of planted Douglas-fir. Forest Ecol Manag 296: $41-52$

Herrero C, Pando V, Bravo F (2010) Modelling coarse woody debris in Pinus spp. plantations. A case study in Northern Spain. Ann For Sci 67:708

Jacobson S, Högbom L, Ring E, Nohrstedt HÖ (2017) The distribution of logging residues and its impact on seedling establishment and early plant growth in two Norway spruce stands. Scand J Forest Res 32: 134-141 
Janisch JE, Harmon ME, Chen H, Fasth B, Sexton J (2005) Decomposition of coarse woody debris originating by clearcutting of an old-growth conifer forest. Ecosci 12:151-160

Jerabkova L, Prescott CE, Titus BD, Hope GD, Walters MB (2011) A meta-analysis of the effects of clearcut and variable-retention harvesting on soil nitrogen fluxes in boreal and temperate forests. Can J For Res 41:1852-1870

Jurevics A, Peichl M, Olsson BA, Strömgren M, Egnell G (2016) Slash and stump harvest have no general impact on soil and tree biomass $\mathrm{C}$ pools after 32-39 years. Forest Ecol Manag 371:33-41

Kimmins J (1997) Forest ecology: a foundation for sustainable management, 2nd edn. Prentice Hall, New Jersey

Kishchuk B, Quideau S, Wang Y, Prescott C (2014) Long-term soil response to variable-retention harvesting in the EMEND (Ecosystem Management Emulating Natural Disturbance) experiment, northwestern Alberta. Can J Soil Sci 94:263-279

Kurth VJ, Bradford JB, Slesak RA, D’Amato AW (2014) Initial soil respiration response to biomass harvesting and green-tree retention in aspen-dominated forests of the Great Lakes region. Forest Ecol Manag 328:342-352

Lehto T, Ruuhola T, Dell B (2010) Boron in forest trees and forest ecosystems. Forest Ecol Manag 260:2053-2069

MacLachlan IR, Wang T, Hamann A, Smets P, Aitken SN (2017) Selective breeding of lodgepole pine increases growth and maintains climatic adaptation. Forest Ecol Manag 391:404-416

Morris DM, Hazlett PW, Fleming RL, Kwiaton MM, Hawdon LA, Leblanc JD, Primavera MJ, Weldon TP (2019) Effects of biomass removal levels on soil carbon and nutrient reserves in conifer-dominated, coarse-textured sites in northern Ontario: 20-year results. Soil Sci Soc Am J 83:S116

Nambiar ES, Kallio MH (2008) Increasing and sustaining productivity in tropical forest plantations: making a difference through cooperative research and partnerships. In: Nambiar EKS (ed) Site management and productivity in tropical plantation forests: workshop proceedings. Center for International Forestry Research.

Nelson KN, Turner MG, Romme WH, Tinker DB (2016) Landscape variation in tree regeneration and snag fall drive fuel loads in 24year old post-fire lodgepole pine forests. Ecol Appl 26:2422-2436

Nettles J, Birks P, Sucre E, Bilby R (2015) Sustainable production of bioenergy feedstock from the industrial forest: potential and challenges of operational scale implementation. Curr Sust/Renew Energ Rep 2:121-127

Olsson BA, Staaf H, Lundkvist H, Bengtsson J, Kaj R (1996) Carbon and nitrogen in coniferous forest soils after clear-felling and harvests of different intensity. Forest Ecol Manag 82:19-32

Parolari AJ, Porporato A (2016) Forest soil carbon and nitrogen cycles under biomass harvest: stability, transient response, and feedback. Ecol Model 329:64-76

R Core Team (2016) R: A language and environment for statistical computing. R Foundation for Statistical Computing, Vienna, Austria. 2015, URL http://www.R-project.org.

Reid AM, Chapman WK, Kranabetter JM, Prescott CE (2015) Response of lodgepole pine health to soil disturbance treatments in British Columbia, Canada. Can J For Res 45:1045-1055

Sagar RM, Waterhouse M (2015) Microclimate studies in mountain pine beetle-damaged silvicultural systems on the Chilcotin Plateau: the Itcha-llgachuz project (1997-2003), Province of British Columbia, Technical Report, p 089. www.for.gov.bc.ca/hfd/pubs/Docs/Tr/ Tr089.htm.
Sagar R, Waterhouse M, Chapman B (2005) Microclimate studies in silvicultural systems on the Chilcotin Plateau of British Columbia: the Itcha-llgachuz Project (1997-2003). British Columbia Ministry of Forests and Range, Forest Science Program. Technical Report, No. 022.

Sanborn PT (2001) Influence of broadleaf trees on soil chemical properties: a retrospective study in the Sub-Boreal Spruce Zone, British Columbia, Canada. Plant Soil 236:75-82

Sanchez FG, Tiarks AE, Kranabetter JM, Page-Dumroese DS, Powers RF, Sanborn PT, Chapman WK (2006) Effects of organic matter removal and soil compaction on fifth-year mineral soil carbon and nitrogen contents for sites across the United States and Canada. Can J For Res 36:565-576. https://doi.org/10.1139/x05-259

Scott DA, Dean TJ (2006) Energy trade-offs between intensive biomass utilization, site productivity loss, and ameliorative treatments in loblolly pine plantations. Biomass Bioenergy 30:1001-1010

Smolander A, Törmänen T, Veikko Kitunen V, Lindroos AJ (2019) Dynamics of soil nitrogen cycling and losses under Norway spruce logging residues on a clear-cut. Forest Ecol Manag 449. https://doi. org/10.1016/j.foreco.2019.06.041

Sterner RW, Elser JJ (2002) Ecological stoichiometry: the biology of elements from molecules to the biosphere. Princeton, New Jersey

Thiffault E, Hannam KD, Paré D, Titus BD, Hazlett PW, Maynard DG, Brais S (2011) Effects of forest biomass harvesting on soil productivity in boreal and temperate forests-a review. Environ Rev 19:278309

Thomas AD, Walsh RP, Shakesby RA (2000) Post-fire forestry management and nutrient losses in eucalyptus and pine plantations, Northern Portugal. Land Degrad Dev 11:257-271

Turner MG, Whitby TG, Tinker DB, Romme WH (2016) Twenty-four years after the Yellowstone Fires: are postfire lodgepole pine stands converging in structure and function? Ecology 97:1260-1273

Vanguelova E, Pitman R, Luiro J, Helmisaari H (2010) Long term effects of whole tree harvesting on soil carbon and nutrient sustainability in the UK. Biogeochemistry 101:43-59

Walmsley J, Jones D, Reynolds B, Price M, Healey J (2009) Whole tree harvesting can reduce second rotation forest productivity. Forest Ecol Manag 257:1104-1111

Waterhouse M, Wallich E, Daintith N, Armleder H (2010) Planted stock performance 10 years after partial cutting in west-central British Columbia. For Chron 86:118-129

Wei X, Kimmins J, Peel K, Steen O (1997) Mass and nutrients in woody debris in harvested and wildfire-killed lodgepole pine forests in the central interior of British Columbia. Can J For Res 27:148-155

Wei X, Kimmins J, Zhou G (2003) Disturbances and the sustainability of long-term site productivity in lodgepole pine forests in the central interior of British Columbia - an ecosystem modeling approach. Ecol Model 164:239-256

Wei X, Li Q, Waterhouse M, Armleder H (2012) Organic matter loading affects lodgepole pine seedling growth. Environ Manag 49:11431149

Wu J, Wei X, Waterhouse M, Qi G (2020) Long-term logging residue loadings affect tree growth but not soil nutrients in lodgepole pine forests. V4. Dryad. [Dataset] https://doi.org/10.5061/dryad. $51 \mathrm{c} 59 \mathrm{zw} 4 \mathrm{z}$.

Publisher's note Springer Nature remains neutral with regard to jurisdictional claims in published maps and institutional affiliations. 